\title{
Analysis on the Development Path of Public Art
}

\author{
Binghao Qu \\ Xi'an Academy of Fine Arts, Xi'an, Shaanxi, 710065
}

Keywords: Development Path, Public Art, Society Science

\begin{abstract}
Public art belongs to the field of contemporary art, which makes the art of public space and the public have a mutual influence, embodies the public space democracy, open, exchange, sharing a spirit and attitude. Compared with classical art and modernist art, the most striking feature is its publicity. "Publicity" as the core concept of public art, the development of public art has an important role. The "public nature" established on the basis of certain civil society and public sphere is the symbol of the free and conscious spirit of the public art. It is the core of the concept of public art and the soul of public art theory. In the practice of public art, the social disputes and public issues related to public interest, public value, power discourse and identity are gradually highlighted, showing the value of public art and the indivisibility of public life. To this end, it is necessary to construct a theoretical framework of the system, and in this theoretical framework of public art "public" to the logical starting point of the analysis.
\end{abstract}

\section{Introduction}

In view of the long history and extensive depth of other research fields, public art as a specialized research object for scholars who are concerned, only in recent decades, both at home and abroad are still a new Research topics. Because public art is both a practical problem and a theoretical research object, and its extensive and complex issues involved in the subject, its philosophy (such as philosophy of value), political science, social communication, cultural criticism and other disciplines Words have different degrees of research value. American scholar Malcolm Miles argues that public art is bound to "urban public and cultural pluralism, the function and attributes of public space, the operation of power, both as a practical category and as a research object As well as the relationship between professional spacebuilders and non-professional urban residents and their role in the role of "and a number of overlapping issues, in the study to use a multi-disciplinary, multi-faceted" theory or research methods to think of art institutions The results of the practice and the public on the public space placed in the public works of art response. Public art is no longer because of its own artistic characteristics, aesthetic form and only cause aesthetics, art history researchers attention.

\section{2. "Public" Construction Premise}

The public domain not only refers to a material entity, it is actually a public behavior by the public and the concept of space. On the ideal type, the public domain is the carrier of public nature, the cradle of public reason. Habermas regards publicity as a historical phenomenon, divides the public domain from the historical point of view, and puts forward the public nature of the ancient Greek "city-state" type, the "representative" type of European medieval nature, the modern bourgeois citizen of western Europe, The shape of the public and other different forms of expression and form. He argues that the public domain has the following characteristics in the mechanism: equality, publicity, openness and criticality. Where criticism is the most notable feature of the public domain. The public domain should be an open platform for public communication, "it will not be in a state of being closed, no matter how exclusive the public is, they will never be isolated." its primary task is to criticize the public power itself, so of course Critical.

In the spatial internal structure of civil society, the public domain includes the literary public 
domain and the political public domain. The former mechanism is embodied in the cafes, salons and literary and artistic clubs, etc., it is the budding public opinion; the latter is the public opinion and public power directly contest the activity space. Hannah Arendt, after examining the public life and private life of the ancient Greeks, pointed out that "the foundation of the city-state was created after the disintegration of natural organizations (such as clans and clan) with ties as family ties, this is not only Aristotle's view or theory, but the basic historical facts. "(2) She distinguishes three areas of human activity, namely, the private sphere, the social sphere, and the public domain. The public domain is a public space that is open, free, eternal, diverse and identically accessible to its reality. "Because of our sense of existence entirely dependent on a show, and therefore depends on the existence of the public domain." In this space field, "everyone continues to distinguish themselves from all the other people, through His unique behavior or achievement to show himself, that he is the best of all. In other words, the public domain is for the personality show; this is also a variety of people show their true style and extraordinary extraordinary place "The public domain is made up of opinions. Everyone expresses only one opinion, and these opinions must be communicated and communicated. So that we can get along with the world to have a more complete understanding, but also in the middle of different views found in the individual differences, uniqueness. In this way, Hannah Arendt combines public domain, action, rational communication with world identity, and points out that the public domain only emerges when people communicate with each other and speak freely and together.

Public art thought itself carries a specific cultural interest, and most of the public domain works that we call "public art" is the art that is created for the public. From this perspective, "the public" is the "viewer", is the indoor and outdoor to "almost all" open private space works of art "viewers". When private space is an open space, specifically it is a space that anyone can use under certain restrictions, it is not a "public space", but a "collective space". As mentioned earlier, Jurgen Habermas argues that the public domain does not exist as a special field of separation from the private sphere in the feudal society in the middle of the Middle Ages. The ruling class came out of the hierarchy and developed into public power. The working class developed into a "civil society" in the urban enterprises and some rural strata. People are keen to come together to discuss a variety of art issues, especially the cafe. The prosperity of the cafes is closely related to people's awareness of communication. At the beginning of the 18th century London had more than 3,000 cafes, each with a relatively fixed customer circle. In the course of the discussion, the art played a role that could not be underestimated: "A public gallery is a book of prints, a play on the stage, and anybody has the right to judge it." "Many of the pamphlets that criticize and maintain the mainstream art theory as objects are inseparable from the discussion in the salon itself, and even the content of the salon discussion - art criticism has become a conversation." "Although the public exhibition can not be permanent, but its function is indispensable. "1 the mid-18th century, art criticism became a professional art. Criticizing activities as a bridge between artists and the general public to communicate.

\section{The Path of Development of Public Art}

In our country, public art is still a relatively new concept. The emergence of this concept and the emergence of public art in the city in the 20th century, 90 years, with the social transformation of the urban public areas continue to increase and the gradual formation of civil society is closely related. It can be said that the deepening of the concept of public art in China's cities and the highlight of its cultural values are the inevitable result of the rapid development of China's social economy, the gradual improvement of the political system and the accelerated pace of urbanization in China. Urbanization is the inevitable outcome of the development of social productive forces to a certain stage, and one of the important civilizations of mankind. Many countries regard urbanization as a measure of their degree of modernization. The public art of the subject into the city's cultural policy point of view, has a very special significance. It is different from the general art, public art can change the whole society for the art of cognition, if the promotion of public art can be 
completely successful implementation of the city will be another face.

Public art has obvious aesthetic characteristics of urbanization is the product of urbanization. With the rapid development of China's urbanization speed, will inevitably lead to the rapid development of urban environmental construction, the development and occurrence of public art is precisely in the small and medium-sized cities in the space, but also for the construction of urban environment and art Design behavior, therefore, it is also the product of urbanization, with a very obvious characteristics of urbanization.

Diversity and artistic form of expression - in this highly informative era, pure art and pure design between the more and more reflect a trend of integration, that is, design art. There are quite a number of practical features of the design works more and more people to consider and appreciate the poetic and artistic association, and the artist is more and more use of new means, new media and new Science and technology to express self-art. Well, public art is a comprehensive new discipline between pure art and pure design. Many disciplines crossed by the formation of the development of Chinese public art, but also conform to this trend, but also a concentrated expression of this trend. Today, the design has been transformed from a concrete technical means to a culture - design culture; and art is no longer high above, above the public, but with social interaction, from the society, the art The goodness of the United States and the universal community, the real use of society, the society is thinking; public art is a more positive attitude to take this social responsibility, to participate in the cause of the human environment to create.

The public domain is a different space from the state power, corresponding to the artistic space under official control. At the same time it should be equal. Art The public domain refers specifically to a social place where art is discussed. This "field" is composed of different identities, different occupations, different ages and different genders, and there is no grade problem and level. Everyone can use their own social strength to express their views, mutual game, "common to comply with a majority of the public recognition of the rules of the game, this rule is not the product of the power of the top-down, nor is it just Coercive force, but a modern society in the common cultural values formed on a set of unspoken rules "to form a view of different views or even oppose the view of the" field. " Each "equal person" can prove its value through this field: either outstanding or dominant, but there can be no only one view and view is the only thing that is eternal truth. They are like the vast stars in the stars, can have friction and collision with each other, but still can "get along" with each other. This field should be of scholarly nature, and there is no "only" and absolute truth. The art public domain should be open. The equality of art in the public domain determines its openness because it is made up of people of different occupations, different identities, ages and different gates, so it should be open. The art of the public domain is also critical. Criticism is the primary function of the public domain, then the corresponding areas of art should also be the first to have a critical function.

\section{Conclusion}

China's public art is still in the stage of development, the rapid development of China to give us these public art students a huge space for development. The full development of Chinese public art is by no means a short process, nor is it a question of old and new topics. It is a dream that requires the willingness of all the artists who are willing to pay quietly, and need the understanding and support of the government and the people. Suitable for the transformation of national conditions only open the public art of vision, the public space energy can be expanded, the quality of public space can continue to improve. From a global perspective, from the 1960s to the present, the percentage of public art has become the western developed countries and some developing countries generally implemented policies for the universal implementation of the countries. The basic content of this policy is from the new project construction, the old project transformation or other environmental construction projects in a certain proportion of funds allocated to the corresponding public art, each city can be different according to the implementation of different specific practices. 


\section{Acknowledgements}

National Art Fund: Research on the design and design of the traditional residential settlement in guanzhong.

\section{References}

[1] Weng Jianqing. Beyond the value of the meaning of the body - public art of the broad sense of ecology [J]. Literature and Art, 2009 (09)

[2] Lu Peng. Changes in Artistic System and Ideas - An Analysis of the Historical Presentations and Problems of the Exhibitions at the Biennale of Shanghai and the Triennial of Guangzhou in the New Century [J]. 2008 (10)

[3] Luo Zidan. Associated experimental art of "Bird's Nest" [J]. Architects, 2008 (03)

[4] Xu Jilin. Internet: the second cultural revolution in human history [J]. University times, 2006 (05)

[5] Sun Zhenhua. Public art of political science [J]. Fine Arts Research, 2005 (02)

[6] Sun Zhenhua. Public art of public nature [J]. Art observation, 2004 (11) 